\title{
PENERAPAN MODEL PEMBELAJARAN LEVELS OF INQUIRY UNTUK MENINGKATKAN HASIL BELAJAR SISWA SMK
}

\author{
Febri Sulistiawan ${ }^{1}$, Kamin Sumardi ${ }^{2}$, Ega T. Berman ${ }^{3}$ \\ Universitas Pendidikan Indonesia \\ Jl. Dr. Setiabudhi No. 229 Bandung 40154 \\ mbefebri82@yahoo.com
}

\begin{abstract}
ABSTRAK
Penelitian ini bertujuan untuk mengetahui peningkatkan hasil belajar siswa SMK pada aspek kognitif, afektif, dan psikomotor setelah diterapkan model pembelajaran levels of inquiry. Model pembelajaran levels of inquiry 5 tahapan yaitu discovery learning, interactive demonstration, inquiry lessons, inquiry labs, dan hypothectical inquiry. Adanya tahapan tersebut membuat siswa mengembangkan kemampuan memecahkan masalah dengan cara berfikir kritis analisis-argumentatif, kreatif, dan madiri sehingga siswa diberikan kebebasan dalam menyusun dan merekontruksi sendiri informasi yang telah diperoleh. Penelitian dilakukan pada salah satu SMK Negeri di Kota Cimahi pada kelas XI TPTU B dengan menggunakan metode pre eksperiment jenis one-group pretestposttest design pada materi menentukan fungsi dan kinerja kompresor tata udara domestik dengan sampel 35 siswa. Hasil penelitian menunjukkan hasil belajar siswa pada aspek kognitif dengan gain dinormalisasi sebesar 0.54 dengan kategori sedang. Aspek afektif didapatkan hasil rata-rata IPK 79.14\% dengan kategori cukup. Aspek psikomotor didapatkan hasil rata-rata IPK 78.93\% dengan kategori cukup terampil. Sehingga setelah diterapkan model pembelajaran levels of inquiry mampu meningkatkan hasil belajar siswa baik dari aspek kognitif, afektif, maupun psikomotor.
\end{abstract}

Kata kunci: Levels of Inquiry, kompresor, hasil belajar, berfikir kritis

\section{PENDAHULUAN}

Pada perkembangannya kini sekolah tingkat menengah kejuruan yang menerapkan kurikulum 2013 dalam mata pelajaran perminatan kejuruan adalah SMK Negeri 1 Cimahi. Adapun mata pelajaran peminatan kejuruan diatur menurut Peraturan Pemerintah Nomor 60 Tahun 2014 pasal 5 ayat 4 yang bertujuan untuk mengembangkan kompetensi sikap, kompetensi pengetahuan, dan kompetensi keterampilan peserta didik sesuai dengan minat, bakat, dan kemampuan dalam bidang kejuruan, program kejuruan dan paket kejuruan.

Proses pendidikan di Sekolah Menengah Kejuruan (SMK) bertujuan mempersiapkan peserta didik agar mampu memilih karir, memasuki lapangan kerja, berkompetensi, dan mengembangkan dirinya dalam menghadapi kemajuan ilmu pengetahuan dan teknologi. Adanya tujuan tersebut sekolah menengah kejuruan lebih meningkatkan kemampuan psikomotor atau keterampilan dengan presentase $70 \%$, sedangkan pada kemampuan kognitif

\footnotetext{
${ }^{1}$ Mahasiswa Departemen Pendidikan Teknik Mesin FPTK, UPI

${ }^{2}$ Dosen Departemen Pendidikan Teknik Mesin FPTK, UPI

${ }^{3}$ Dosen Departemen Pendidikan Teknik Mesin FPTK, UPI
} 
hanya dibebankan pada peserta didik dengan presentase $30 \%$. Berdasarkan tujuan tersebut diperlukan suatu instrumen peningkatan mutu pendidikan yaitu tujuan, metode, dan isi.

Kurang efektifnya metode yang berpusat pada guru membuat siswa menjadi pasif, dan hanya menerima informasi. Sehingga pada proses pembelajaran siswa tidak memiliki kebebasan berfikir dan kurang menggali informasi yang diterimanya. Akibatnya pembelajaran di kelas menjadi kurang menarik perhatian siswa sehingga kemampuan siswa dalam memahami dan menguasai materi yang diikutinya menjadi rendah. Hal ini yang menjadikan kondisi pembelajaran cenderung monoton dan siswa kurang aktif dalam mengikuti pelajaran.

Studi pendahuluan di SMK yang berada di kota Cimahi pada mata pelajaran sistem dan instalasi tata udara pada materi menentukan fungsi dan kinerja kompresor tata udara domestik masih banyak siswa yang mendapatkan nilai yang berada di bawah KKM. Terbukti kemampuan kognitif pada KKM $\geq 75$ untuk kelas XI TPTU A dari 34 siswa, 76.5\% siswa memenuhi KKM dan $23.5 \%$ siswa yang belum memenuhi KKM. Sedangkan pada kelas XI TPTU B dari 34 siswa, $61.7 \%$ yang memenuhi KKM dan 38.3\% siswa yang belum memenuhi $\mathrm{KKM} \geq 75$.

Hal ini menjadi rujukan bahwa masih adanya siswa yang memiliki kemampuan kognitif di bawah standar kelulusan. Pembelajaran yang masih berpusat pada guru membuat siswa menjadi pasif, dan hanya menerima informasi. Sehingga pada proses pembelajaran siswa tidak memiliki kebebasan berfikir dan kurang menggali informasi yang diterimanya. Akibatnya pembelajaran di kelas menjadi kurang menarik perhatian siswa sehingga kemampuan siswa dalam memahami dan menguasai materi yang diikutinya menjadi rendah. Hal ini yang menjadikan kondisi pembelajaran cenderung monoton dan siswa kurang aktif dalam mengikuti pelajaran.

Perlu adanya solusi agar proses pembelajaran dapat lebih efektif dan siswa bisa lebih aktif dalam proses pembelajaran. Adapun model pembelajaran levels of inquiry yang merupakan suatu kerangka pembelajaran yang disusun secara sistematis untuk memproses pemahaman siswa secara efektif. Pada levels of inquiry terdapat 5 tahapan yang terstruktur dalam pembelajaran inkuiri. Model pembelajaran levels of inquiry ini berupa spektrum inkuiri yang didalamnya terdiri dari tahapan discovery learning, interactive demonstration, inquiry lessons, inquiry labs, dan hypothetical inquiry (Wenning, 2011). 
Model pembelajaran levels of inquiry berbasis kepada kedua hal yaitu kecerdasan intelektual (intellectual sophistication), dan pihak pengontrol (locus of control). Pihak pengontrol bergerak dari guru ke siswa secara berkesinambungan, dimulai dengan kegiatan discovery learning yang mana guru memegang kendali kegiatan pembelajaran, dan kontrol ini berangsur-angsur berkurang dan berpindah ke siswa hingga kegiatan hypothectical inquiry. Sedangkan untuk kecerdasan intelektual penggunaanya secara berkesinambungan meningkat dari discovery learning hingga menuju hypothectical inquiry (Wenning, 2005). Oleh karena itu, dengan melewati tahapan-tahapan spektrum inkuiri siswa akan mendapatkan pemahaman materi yang komprehesif dari seluruh kemampuan proses saintifik dan intelektual. Sehingga sasaran utama kegiatan pembelajaran inkuiri adalah keterlibatan siswa secara maksimal dalam proses kegiatan belajar, keterarahan kegiatan secara logis dan sistematis pada tujuan pembelajaran, dan mengembangkan sikap percaya diri pada siswa tentang apa yang ditemukan dalam proses inkuiri (Trianto, 2007).

Penerapan dari model pembelajaran levels of inquiry dapat meningkatkan literasi sains siswa, domain kompetensi, dan pengetahuan literasi sains (Dahtiar, 2015). Sedangkan pembelajaran yang menerapkan model pembelajaran levels of inquiry lebih baik dari model pembelajaran konvensional yang diterapkan oleh guru begitu juga dengan respon siswa terhadap pembelajaran berorientasi levels of inquiry termasuk dalam kategori baik (Sutarja dan Hasanah, 2014).

Adanya dampak yang positif tersebut penerapkan model pembelajaran levels of inquiry dirasa pantas diterapkan untuk mata pelajaran produktif pada materi menentukan fungsi dan kinerja kompresor tata udara domestik. Tujuannya untuk meningkatan hasil belajar siswa sesuai dengan standar kompetensi kelulusan. Adapun hasil belajar siswa pada sistem pendidikan nasional menggunakan klasifikasi Benyamin Bloom yang secara garis besar membagi menjadi tiga ranah yakni ranah kognitif, ranah afektif, dan ranah psikomotor (Sudjana, 2016).

Sehingga setelah diterapkan model pembelajaran levels of inquiry siswa terlibat dalam pembelajaran, merumuskan pertanyaan, menyelidiki secara luas, dan kemudian membangun pemahaman baru, makna, dan pengetahuan yang baru bagi siswa serta dapat digunakan untuk menjawab pertanyaan, mengembangkan solusi atau mendukung suatu posisi menurut sudut 
pandang (Alberta, 2004). Dengan demikian, diharapkan hasil belajar siswa bisa lebih baik karena siswa terlibat langsung dalam proses pembelajaran.

\section{METODE PENELITIAN}

Penelitian ini desain yang digunakan yaitu pre eksperimental. Jenis pre eksperimental yang digunakan pada penelitian ini adalah one-grup pretest-posttest design. Jenis ini dipakai karena dalam penelitian ini yang menjadi subjek penelitian hanya kelas eksperimen saja tanpa adanya kelas kontrol atau pembanding. Tujuan menggunakan desain ini adalah untuk mengetahui peningkatan kemampuan kognitif, afektif, dan psikomotor siswa setelah diterapkan model pembelajaran levels of inquiry bukan membandingkan model pembelajaran levels of inquiry dengan model pembelajaran yang lain.

Pada penelitian ini sampel menggunakan sampling purposive. Sampel pada penelitian ini yaitu kelas XI TPTU B (sebagai kelas eksperimen). Jumlah sampel pada penelitian ini sebanyak 35 orang. Kelas ini dipilih berdasarkan hasil observasi, kemampuan siswa didalamnya memiliki pemahaman konsep yang masih rendah dan siswa lebih aktif dalam proses pembelajaran.

Instrumen yang digunakan pada penelitian ini berupa tes dan non tes. Pada instrumen tes mencakup tes hasil belajar aspek kognitif. Sedangkan pada instrumen non tes mencakup lembar observasi penilaian afektif dan psikomotor serta lembar keterlaksanaan model pembelajaran levels of inquiry.

\section{HASIL PENELITIAN}

Hasil peningkatan pada aspek kognitif yang diukur melalui pretest dan posttest dari 30 soal. Hasil tersebut sudah diringkas pada Tabel 1.

Tabel 1. Peningkatan Rata-Rata Pretest-Posttest

\begin{tabular}{ccccccc}
\hline \multirow{2}{*}{ No } & \multirow{2}{*}{ Nilai } & \multirow{2}{*}{$\mathrm{N}$} & \multicolumn{4}{c}{ Nilai } \\
\cline { 4 - 7 } & & Skor ideal & Nilai Minimal & Nilai Maksimal & Rerata \\
\hline 1 & Pretest & 35 & 100 & 40 & 72 & 58,06 \\
2 & Posttest & 35 & 100 & 72 & 92 & 81,03 \\
& & \multicolumn{2}{c}{$<\mathrm{g}>$} & & & 0,54 \\
& & \multicolumn{2}{c}{ Kategori } & Sedang \\
\hline
\end{tabular}


Setelah itu pengujian hipotesis menggunakan pengujian Paried T-Test. Hasil didapatkan perolehan thitung sebesar -17.2, sementara untuk tabel dengan derajat kebebasan (df) $=\mathrm{n}-2$ atau 35-2 = 33 dan sig. $0.05=2$. Dari hasil perhitungan thitung $=-17.2$ dan $t_{\text {tabel }}=-2$. Jika nilai thitung lebih kecil daripada tabel atau $-2>-17.2$, maka dengan demikian Ha diterima. Kesimpulannya bahwa penerapan model pembelajaran levels of inquiry mampu meningkatkan hasil belajar siswa pada materi menentukan fungsi dan kinerja kompresor tata udara domestik.

Adapun untuk hasil belajar aspek afektif siswa yang diamati selama pembelajaran, (receiving), aktif mengikuti diskusi kelompok (responding), bertanggung jawab saat melakukan praktikum (valuing), kecermatan dalam mengambil data praktikum (organization), dan mengkomunikasikan hasil praktikum (characterization). Hasil penelitian dapat dilihat pada Tabel 2.

Tabel 2. Hasil Belajar Aspek Afektif

\begin{tabular}{clcc}
\hline No & Kriteria Penilaian & Skor Rata-rata & Kategori \\
\hline 1 & Receiving & $75.71 \%$ & Baik \\
\hline 2 & Responding & $77.86 \%$ & Baik \\
\hline 3 & Valuing & $77.86 \%$ & Baik \\
\hline 4 & Organization & $78.57 \%$ & Baik \\
\hline 5 & Characterization & $85.71 \%$ & Baik \\
\hline & Rata-rata $(\bar{x})$ & $79.14 \%$ & Baik \\
\hline
\end{tabular}

Pada hasil belajar siswa aspek psikomotor yang diambil berdasarkan waktu siswa melakukan kegiatan praktikum adapun aspek yang diamati meliputi menggunakan keselamatan kerja, menyiapkan alat dan bahan, menggunakan alat ukur, merangkai alat praktikum, melakukan praktikum, dan mengambil data hasil praktikum. Adapun hasil penelitian aspek psikomotor disajikan pada Tabel 3.

Tabel 3. Hasil Belajar Aspek Psikomotor

\begin{tabular}{clccc}
\hline No & \multicolumn{1}{c}{ Kriteria Penilaian } & Skor rata-rata & $\%$ & Kategori \\
\hline 1 & Menggunakan alat keselamatan kerja & 75 & $75 \%$ & Sangat Baik \\
\hline 2 & Menyiapkan alat dan bahan praktikum & 89.9 & $89.9 \%$ & Sangat Baik \\
\hline 3 & Menggunakan alat ukur & 77.1 & $77.1 \%$ & Baik \\
\hline 4 & Merangkai alat praktikum & 77.1 & $77.1 \%$ & Baik \\
\hline 5 & Melakukan praktikum sesuai prosedur & 77.1 & $77.1 \%$ & Baik \\
\hline 6 & Mengambil data hasil praktikum & 79.3 & $79.3 \%$ & Baik \\
\hline & Rata-rata $(\bar{x})$ & 78.93 & $78.9 \%$ & Sangat Baik \\
\hline
\end{tabular}




\section{PEMBAHASAN}

Pada aspek kognitif menunjukkan bahwa dengan menggunakan model pembelajaran levels of inquiry mampu meningkatkan hasil belajar siswa. Sebanyak 35 siswa didapatkan hasil belajar kognitif setelah diterapkan model pembelajaran levels of inquiry hanya 2 siswa masih memiliki nilai masih dibawah nilai KKM (Kriteria Kelulusan Minimum) yaitu 75. Hal ini menunjukkan bahwa siswa menunjukan cara berfikir siswa siswa yang kritis analisisargumentatif, kreatif, dan mandiri dalam menyelesaikan masalah terkait materi yang disampaikan guru. Sehingga rasa antusias dan termotivasi siswa dalam mengikuti pembelajaran dan mampu merekontruksikan pengetahuan melalui kegiatan inquiry.

Pada aspek afektif menunjukkan skala sikap siswa setelah diterapkan model pembelajaran levels of inquiry baik saat pembelajaran, mengikuti diskusi, melakukan praktikum, mengambil data praktikum, dan mengkomunikasikan hasil terbilang cukup terampil. Sehingga siswa sangat antusias dalam mengikuti setiap pembelajarannya dan siswa terlibat secara langsung dengan materi pelajaran melalui sumber yang ada di lingkungan sekitar sebagai sumber belajar.

Pada aspek psikomotor menunjukkan kemampuan berinkuiri terutama pada level inquiry lessons dan inquiry labs tergolong terampil dalam melakukan setiap kegiatan praktikumnya. Peningkatan hasil belajar keterampilan siswa membuktikan bahwa pemanfaatan benda yang ada dilingkungan sekitar sebagai sebagai sumber belajar dapat mendorong aktivitas siswa dalam kegiatan pembelajaran

\section{KESIMPULAN}

Penelitian ini dapat disimpulkan bahwa peningkatan hasil belajar pada ranah kognitif, afektif, dan psikomotor pada materi menentukan fungsi dan kinerja tata udara domestik. Hal ini dapat di indikasikan bahwa model pembelajaran yang diterapkan guru harus memiliki strategi dan metode yang tepat, efisien, efektif, dan mengena pada tujuan pembelajaran yang di harapkan. Hal tersebut diperlukan dalam mengembangkan motivasi siswa secara aktif, menarik minat siswa, dan perhatian siswa sehingga dapat meningkatkan hasil belajar siswa secara optimal. 


\section{REFERENSI}

Alberta. (2004). Focus on Inquiry: A Teacher's Guide to Implementing Inquiry-based Learning. Canada: Alberta Learning.

Dahtiar. (2015). Pembelajaran Levels of Inquiry Meningkatkan Literasi Sains Siswa SMP pada Konteks Energi Alternatif. Bandung: Prosiding Simposium Nasional Inovasi dan Pembelajaran Sains 2015 (SNIPS 2015), hlm. 197-200.

Sudjana, N. (2016). Penilaian Hasil Proses Belajar Mengajar. Bandung: PT. Remaja Rosdakarya.

Sutarja, M, C dan Hasanah, R. (2014). Penerapan Pembelajaran Berorientasi Levels of Inquiry terhadap Hasil Belajar pada Sub-Pokok Materi Fluida Statis. Jurnal Inovasi Pendidikan Fisika (IIPF) (3) 3, hlm. 72-79. [Online]. Tersedia: http://www.unesa.edu (15 Agustus 2016).

Trianto. (2007). Model-Model Pembelajaran Inovatif Berorientasi Konstruktivistik. Jakarta: Prestasi Pustaka Publisher.

Wenning, C, J. (2005). Levels of Inquiry: Hierachies of Pedagogical Practies and Inquiry Process. Journal of Physics Teacher Education Online (2) 3, hlm.3-16. [Online]. Tersedia: http://www.phy.ilstu.edu. (10 Juni 2016).

Wenning, C, J. (2011). The Levels of Inquiry Model of Science Teaching. Journal of Physics Teacher Education Online (6) 2, hlm. 9-16. [Online]. Tersedia: http://www.phy.ilstu.edu. (10 Juni 2016). 